\title{
INTEGRASI ISLAM DAN BUDAYA LOKAL DALAM SENI ARSITEKTUR MASJID KUNO DI JAWA: SEBUAH TINJAUAN UMUM
}

\author{
INTEGRATION OF ISLAM AND LOCAL CULTURE IN THE \\ ARCHITECTURE OF ANCIENT MOSQUE IN JAVA: AN OVERVIEW
}

\author{
Ahmad Zainuri ${ }^{1}$ \\ ${ }^{1}$ Pascasarjana UIN Sunan Kalijaga Yogyakarta \\ email: ahmadsultanzain1986@gmail.com
}

\begin{tabular}{l} 
INFORMASI ARTIKEL \\
\hline Diterima: 17 Oktober 2021 \\
Direvisi: 29 Desember 2021 \\
Publikasi Online: \\
31 Desember 2021 \\
KATA KUNCI \\
\hline Islam, Budaya Lokal, \\
Arsitektur, Masjid
\end{tabular}

\begin{abstract}
This article will explain about the integration of Islam and local culture in the architecture of ancient mosques in Java. The architecture of the ancient mosque to this day is still considered to have a deep meaning. The encounter with local culture and Islam, made Islam transformed into a religion that sees the existing reality. Civilization is in the form of a physical stand firmly in its nuances of locality. Mosques are historical relics for Muslims as evidence that Islamic history has succeeded in bringing civilization to a stop in Java. The mosque is a center for da'wah, education and socio-religious activities. So the establishment of the mosque is not a matter of physical considerations, but metaphysical. The method that the author uses is the historical method. This article only looks at an overview of the architecture of ancient mosques in Java. The content of the discussion describes how Islamic architecture in Java, architectural development, integration of Islam and culture in the art of ancient mosque architecture in Java. In conclusion, there is no certain standard in building and establishing mosques in Java. The architectural style of Javanese Islamic mosques has given its own characteristics for Islam in Java.
\end{abstract}

\begin{abstract}
A B S T R A K
Artikel ini akan menjelaskan tentang integrasi Islam dan budaya lokal pada arsitektur masjid kuno di Jawa. Arsitektur masjid kuno hingga hari ini masih dianggap memiliki sebuah makna yang mendalam. Perjumpaan dengan budaya lokal dan Islam, menjadikan Islam menjelma menjadi agama yang melihat realitas yang ada. Peradabannya pun yang berupa fisik berdiri kokoh dalam balutan nuansa lokalitas. Masjid sebagai peninggalan bersejarah bagi umat Islam sebagai bukti bahwa sejarah Islam telah berhasil membawa peradabannya singgah di Jawa. Masjid menjadi pusat dakwah, pendidikan dan kegiatan sosial keagamaan. Sehingga berdirinya masjid
\end{abstract}


bukan soal pertimbangan fisik, tapi metafisik. Metode yang penulis gunakan ialah metode sejarah. Artikel ini hanya melihat pada tinjauan umum pada arsitektur masjid-masjid kuno di Jawa. Adapun isi pembahasan menguraikan bagaimana arsitektur Islam di Jawa, perkembangan arsitektur, integrasi Islam dan budaya pada seni arsitektur masjid kuno di Jawa. Kesimpulannya tidak ada pakem tertentu dalam membangun dan mendirikan masjid di Jawa. Gaya arsitektur masjid Islam Jawa, telah memberikan ciri khas tersendiri bagi Islam di Jawa.

\section{Pendahuluan}

Arsitektur Islam tidak pernah lepas dari masalah kebudayaan Islam. Arsitektur Islam sebagai bagian dari Islamic Culture itu merupakan hasil usaha manusia yang berwujud kongkrit dalam sebuah upaya untuk memenuhi kebutuhan jasmani dan rohani. Jasmaniah, karena arsitektur Islam merupakan tempat yang berupa bangunan-bangunan untuk menampung kegiatan manusia. Sedangkan rohaniah, karena memang telah menjadi kenyataan di mana Islam berpengaruh amat mendalam terhadap kehidupan kejiwaan manusia. Selama berabad-abad semasa penyebaran Islam telah merubah sikap hidup bangsa-bangsa yang telah terjangkau. Bertolak dari tanah Arab, kemudian menyebar luas ke Timur melalui Mesopotamia, Persia, Turki sampai ke daerah lembah sungai Indus (sungai yang terdapat di Asia yang tepatnya di India). Sedangkan proses penyebaran Islam ke Barat menyusup jauh ke Maroko. Kemudian dalam perkembangan selanjutnya, melaju terus melalui berbagai benua dan mengarungi samudra hingga sampai ke daerah Cina dan sampai ke Indonesia dan masuk pula ke wilayah Afrika dan Eropa (Rochym, 1983, p. 2).

Dalam Islamisasi di Indonesia (Nusantara), Islam menjelma dengan realitas yang ada. Misalnya penyebaran Islam oleh para wali, yang kita kenal dengan sebutan Walisongo, dalam prosesnya tidak langsung mengajarkan Islam ala Arab atau Timur Tengah, melainkan mencoba melihat keadaan sekitar. Layaknya seperti Sunan Kalijaga, yang memang hampir penuh kajian-kajian keislaman yang dibawanya ialah berbau kebudayaan lokal (Jawa) yang adanya sebuah keterpaduan dengan Islam. melihat masyarakat Jawa yang masih menganut erat akan adat istiadat Jawa, sehingga Sunan Kalijaga atau wali lainnya, tidak memaksakan kehendak dakwah dengan cara puithan. Sehingga banyak cara yang bisa ditampilkan sebagai media dakwah untuk menyiarkan Islam.

Misalnya Delly menjelaskan memang Islamisasi di Indonesia tidak pernah lepas dari sebuah akulturasi budaya lokal. Untuk apa? Tujuan ini ialah untuk menyesuaikan dengan 
keadaan setempat. Sehingga Islam bisa meramahkan diri hingga masuk pada jiwa-jiwa manusia. Dalam prosesnya, banyak peninggalan sejarah yang ditinggalkan oleh Walisongo maupun wali-wali lainnya dalam proses penyebaran Islam di Indonesia.(Rachman et al., 2018, p. 29). Misalnya masjid, makam dan maupun kedaton (keraton, istana) sebabagi pusat pemerintahan kedinastian Islam yang kala itu berdiri sebagai pengendali pemerintahan. Layaknya Nabi Muhammad Saw dalam syiarnya ke Yastrib (Madinah) bahwa peradaban Islam yang pertama di bangun ialah masjid, kenapa? Karena masjid menjadi poros atau pusat kegiatan umat Islam (Ismail, 2017, p. 100).

Dalam usaha Islamisasi di Indonesia setidaknya ada 6 jalur, salah satunya ialah jalur seni dan budaya. Sebuah cara lain dalam prosesi perkenalan Islam di Indonesia ialah dengan cara seni dan budaya. Cara ini dilakukan oleh Walisongo/ ulama penyebar Islam lainnya saat mensyiarkan Islam. dengan menggunakan cara ini, penyebaran Islam bisa menjangkau masyarakat pelosok, yang saat itu tetap suka dengan pertunjukkan seni dan budaya, salah satunya wayang (Aizid, 2016, p. 33). Tidak lain juga nuansa seni arsitektur juga diwariskan oleh para ulama/Walisongo dalam bentuk bangunan, misalnya arsitektur masjid Demak, Masjid Sunan Ampel. Semua itu didesain seklasik mungkin, ala nuansa arsitektur Jawa, corak yang khas dengan gaya bangunan keraton joglo maupun limasan. Ini yang membuat unik pada masjid di Indonesia, terutama Jawa bahwa desain arsitektur tidak melulu berkiblat pada masjid ala Timur Tengah atau Arabia. Melainkan menggunakan kiblat dan corak ala Jawa dengan tetap objek formalnya ialah Masjid sebagai tempat ritual ibadah umat Islam. Adapun makna lainnya yang tersingkap, misalnya berdirinya masjid sebagai daya tarik keindahan, wisata religi, atau wisata sejarah edukasi, ini sudah diluar jangkauan Islam. Namun, itu akan menjadi value bagi perkembangan Islam dan kesejarahan masjid sebagai pusat/objek kajian Islam dengan perjalanan sebagai bangunan bersejarah dalam proses penyebaran Islam di Indonesia khususnya.

Dalam proses penyebaran Islam, memang tidak pernah lepas dari konstruksi sebuah bangunan dalam kebudayaan sebagai peninggalan bersejarah. Misalnya masjid, makam, universitas, madrasah, pesantren, kraton/istana, taman, pusat kota, semua merupakan bangunan yang didirikan atas sebuah tujuan dalam proses dan perkembangan Islam itu sendiri (Aizid, 2015, p. 431). Kita lihat peradaban dunia Islam, mulai dari dinasti Umayyah I, Abbasiyah, Umayyah II, hingga dinasti-dinasti kecil yang berdiri dibawah kaki Abbasiyah, semua tidak lepas dari peradaban kebudayaan Islam, yakni berdirinya masjid sebagai pusat kegiatan umat Islam maupun sebagai pendidikan Islam (Khoiriyah, 2014, p. 38). Semua itu merupakan sebuah peradaban dalam kebudayaan yang berwujud bangunan yang disebut sebagai arsitektur Islam, kalau dalam Rochym tadi dijelaskan sebagai wujud jasmani dan rohani. Pun di Nusantara (Indonesia), banyak peninggalan bersejarah yang hingga kini 
masih dilestarikan dan masih bisa digunakan hingga saat ini bahkan mengalami pemugaran, pembenahan agar lebih kokoh kembali. Misalnya masjid Demak, Masjid Sunan Ampel, Masjid Kudus, Masjid Kraton Yogya. Selain masjid juga ada kraton-kraton yang juga masih berdiri hingga saat ini. Tidak lain, yang membuat unik dan menarik hingga bangunan tersebut masih kokoh ialah karena arsitekturnya yang masih melekat di dinding-dinding, soko gurunya, gentingnya, hiasan temboknya, ukiran seni dalam sudut masjid tersebut. Ini yang kemudian menarik untuk di ulas lebih jauh dan mendalam tentang Seni Arsitektur Masjid di Tanah Jawa, terutama akan sebuah keklasikannya.

\section{Tinjauan Literatur}

\section{Sinkretisme}

Konsep sinkretisme dalam melihat kompleksitas penetrasi budaya yang berkembang, terutama dalam menyikapi gaya arsitektur Islam dalam masjid. Konsep Sinkretisme usaha untuk menghilangkan perbedaan-perbedaan dan menciptakan persatuan antar sekte. Dalam praktiknya misalnya menghilangkan nama Hindu, Budha, Animisme secara lahiriah untuk dileburkan menjadi satu bernama Islam. Dalam arti lain, Sinkretisme ialah percampuran antara dua tradisi atau lebih, yang terjadi ketika masyarakat mengadopsi sebuah agama dan mencoba untuk tidak bertabrakan dengan budaya lama. Dalam pandangan penulis sinkretik ini bisa terpakai pada Islam. Terpenting masjid masih suci, bersih dan sesuai fungsi untuk ibadah, masih bisa. Sinkretis mungkin hampir sama dengan akulturasi, sehingga masjid dengan gaya Jawa, masjid dengan gaya kraton, joglo tidak masalah.(Sutiyono, 2010, p. 64).

\section{Arsitektur Islam}

Arsitektur Islam adalah sebuah karya seni bangunan yang terpancar dari aspek fisik dan matafisik bangunan melalui konsep pemikiran Islam yang bersumber dari al-Quran, Sunnah Nabi, keluarga Nabi, sahabat, ulama dan para cendekiawam Muslim. Pemikiran Islam mencakup nilai-nilai ajaran Islam seperti ketaqwaan kepada Allah SWT, hubungan baik antar makhluk hidup, dan nilai-nilai Islam lainnya. Dalam hal ini, arsitektur Islam tidak hanya berbicara tentang bentuk, tetapi juga berbicara tentang manfaat bagi masyarakat, suasana dalam bangunan, serta fungsi bangunan itu sendiri yang sesuai dengan nilai-nilai Islam. Masjid merupakan salah satu produk aristektur Islam. corak dan bentuk masjid sangat dipengaruhi oleh budaya, suku, di daerah sekitar masjid itu dibangun pada saat itu maupun kini.(Rizky Indriatuty, et al., 2020, p. 121).

\section{Studi Arkeologi}

Perlu penulis pertegas dalam judul untuk memberikan penjelasan kerangka isi secara runtut. 1. Masjid merupakan tempat ibadah umat Islam dan tempat kegiatan keagamaan, 
pendidikan dan dakwah. 2. Arkeologi yakni berupa kajian kebendaan yang bersifat keagamaan dan mempunyai nilai-nilai religius dan historisitas sekaligus juga merupakan simbol agama. Studi merupakan kajian atau telaah ilmiah, sedangkan arkeologi yakni ilmu tentang kehidupan dan kebudayaan zaman kuno berdasarkan kebendaan peninggalan bersejarah, misalnya dalam hal ini masjid.(Fajri \& Aprilia Senja, 2005, p. 1044). Penelitian ini merupakan penelitian sejarah budaya Islam lokal yang mencoba mengintegrasikan dan mengkoneksikan antara keislaman dan kesejarahan dalam konteks lokal yakni berfokus pada arsitektur Islam pada masjid kuno di Jawa.

Ilmu Arkeologi merupakan salah satu ilmu bantu dalam merekonstruksi sejarah dan kebudayaan. Pendekatan arkeologi bagi penelitian sejarah kebudayaan sudah umum dilakukan. Misalnya, seperti arkeologi melalui studi-studi benda (artefak dan bangunan), selain itu adapun fungsi yang lain dari pendekatan arkeologi, seperti memberikan analisis cara pembuatannya, klasifikasi gaya atau corak dan perkembangannya menurut periodesasinya. Dalam konsep ini penulis menggunakan pendekatan arkeologi karena pendekatan arkeologi dalam penelitian sejarah kebudayaan sebagai penelitian yang memfokuskan pada benda-benda buatan manusia. Juga bisa mengetahui proses perubahan kebudayaan atau akulturasi dari zaman Hindu-Budha ke Islam. (Tjandrasasmita, 2009, p. 4);(Ph. Subroto, 1982, p. 6).

Stuart Pigot dalam Uka menjelaskan bahwa arkeologi merupakan suatu disiplin yang mempelajari peristiwa yang tidak disadari dan dibuktikan dengan peninggalan bendabenda yang masih ada, baik itu tertulis atau tidak. Clark menambahkan bahwa studi arkeologi bergantung pada pengklasifikasian artefak dan interpretasi perkembangan gaya arkeologi dan juga perlu memberikan gambaran yang lebih luas tentang bentuk, tekstur, dan gaya artistiknya. Pendekatan arkeologi memperhatikan benda-benda lain sebagai produk budaya masyarakat yang sudah terbiasa dengan tulisan. Pendekatan arkeologis dalam penelitian wisata religi menjadi penting karen dapat memberikan penjelasan tentang sejarah perkembangan religi/agama. (Tjandrasasmita, 2009, p. 8).

\section{Metode}

Metode ini menggunakan penelitian kualitatif dengan studi kepustakaan, yakni dengan melakukan kajian pada buku, artikel yang terkait. Dalam konteks ini, penulis hanya mencoba meneropong kajian ini sebagai dinamika luaran. Dalam artian hanya melihat secara umum terkait arsitektur masjid dan integrasi budaya lokal di Jawa. Pendekatan sejarah dan budaya lokal menjadi analisa untuk mendekati objek kajian. Adapun metode yang penulis gunakan ialah metode sejarah; heuristik, verifikasi, interpretasi dan historiografi sebagai alat penggalian data, sumber.(Gumilar, 2017, p. 39; Kuntowijoyo, 2013, p. 145). 


\section{Hasil \& Diskusi}

\section{Sejarah Arsitektur Islam}

Seni arsitektur Islam dapat dilihat secara tersendiri yang memang nyata kehadirannya dalam sejarah sebagai bagian yang terpenting dalam peradaban umat Islam. Dalam hal ini, arsitektur juga bisa ditafsirkan pada batas bangunan, tapi juga bisa dijelaskan hingga falsafah/filososfi dari banguna tersebut. Dalam hal ini, penulis akan mencoba merekonstruksi seni arsitektur masjid klasik di Jawa. Misalnya bagaimana arsitektur masjid di Jawa? Apakah sama dengan arsitektur di Timur Tengah, Arabia? Mengapa arsitektur masjid di Jawa bisa berbeda? Apakah ini sebagai seni Islam dalam nuansa kearifan lokal? Mungkin itu beberapa rumusan pancingan dalam menuliskan artikel ini.

Wujud Arsitektur Islam secara fisik, ternyata juga menarik perhatian. Sebab daripadanya, muncul bentuk kerangka-kerangka yang dihasilkan oleh penganut Islam. Hal itu berupa bangunan-bangunan yang dihasilkan oleh orang Islam sebagai fasilitas pelaksanaan kegiatan keislaman yang berwujud arsitektur religi maupun non-religi. Pertama-tama muncullah bangunan masjid. Masjid yang merupakan sebagai bangunan religi berpadu dari fungsi bangunan sebagai arsitektur yang juga berpedoman oleh ketentuan peribadatan sesuai lokus kegiatan keagamaan. Maka tampillah arsitektur masjid dengan segala bentuk, gaya, corak dan penampilannya yang khas dari setiap masa ke masa. Itu karena setiap daerah memiliki kehidupan dengan adat dan kebiasaannya, serta latar belakang manusia yang menciptakannya.(Rochym, 1983, p. 3).

Kemudian muncul konstruksi di luar bangunan masjid yang juga masih rangkaian keislaman, yaitu bangunan yang sifatnya non-religi yang berfungsi sebagai fasilitas kebutuhan manusia. Misalnya istana/keraton, puri, benteng pertahanan, makam/kuburan, yang semuanya memiliki pola yang sama dengan penampilannya bangunan masjid. Penampilan struktur tersebut merupakan sebagai sarana tambahan yaitu di saat Islam telah berkembang sedemikian majunya, sehingga para pendukung Islam telah menemukan kemungkinan-kemungkinan guna melahirkan tata letak yang megah dan tinggi nilainya dalam kestetisannya.

Arsitektur Islam dalam Rochym sudah jelas, bahwa ada dua setidaknya antara religi dan non-religi. Ini menandakan begitu luasnya makna yang tersemat pada arsitektur Islam sendiri. Sativa mencatat arsitektur Islam sebagian besar diartikan pada sebuah aspek bentuk, langgam, peninggalan historis, dan hal lainnya yang bersifat fisik yang juga dianggap merupakan bagian dari kebudayaan umat Islam. Namun, ketika mengaca ketika masa Nabi Muhammad Saw mendirikan masjid Quba, Nabawi, tidak begitu terlihat kearsitekturan yang indah. Hanya menggunakan pohon kurma, daun kurma dan benda-benda lainnya, yang memang tujuannya hanya untuk peribadatan umat Islam. Sehingga gaya arsitektur lslam 
yang mencolok baru berkembang setelah kebudayaan Muslim memadukannya dengan gaya arsitektur Roma, Mesir, Persia dan Byzantium. Seperti nampak pada masjid Cordova, Spanyol. Gaya arsitektur yang mencolok dari bangunannya misalnya ruang tengah yang luas dan terbuka, banguna yang melingkar dan penggunaan pola kaligrafi. (Sativa, 2011, p. 32).

Arsitektur Islam dalam kajian ini akan membahas seni arsitektur masjid di Jawa. Kalau Fikriarini menjelaskan arsitektur termasuk di dalamnya terdapat seni ruang yang mendukung kemajuan Islam. keberadaan seni ruang yang didalamnya terdapat bidang arsitektur merupakan suatu hal yang penting. Sehingga pembangunan fisik peradaban ini senantiasa selalu berlandaskan nilai-nilai Islam. Selain makna Islam dan bentuk fisiknya, arsitektur Islam menekankan pada gaya yang menampilkan keindahan yang kaya akan makna (filosofis), simbolisme dan estetikanya.(Fikriani, 2010, p. 197).

Arsitektur Masjid di Jawa begitu banyak ragam coraknya. Baik yang bercorak Timur Tengah, Eropa atau bercorak ala Jawa. Ini merupakan keunikan yang terdapat pada masjid di Indonesia dalam rentang era klasik hingga modern. Gaya limasan, joglo dalam pembuatan masjid di Jawa menjadi salah satu corak yang khas. Terutama wilayah pedesaan atau setingkat kecamatan, masjid menampilkan gaya arsitektur Islam yang tradisionalis. Namun, ketika sudah melihat masjid yang setara kabupaten atau nasional, corak dan gaya masjid sudah berarsitektur ala Eropa dan cirinya sudah tidak menggunakan genteng sebagai atapnya, tapi sudah pakai cor beton. Namun, di era modern ini, masjid di pedesaan pun sudah bertransformasi menjadi masjid yang berarsitektur nasional.

Masjid di pedesaan lebih mengutamakan simbolis dan filsofisnya. Misalnya yang disebutkan di atas, bahwa masjid di pedesaan banyak berarsitektur ala Jawa, seperti limasan, yakni membangun masjid dengan atas bertumpuk tiga. Selain mendirikan karena simbolis, pastinya menyimpan makna filosofis di dalamnya. Ini merupakan masjid di Jawa, yang masih mempertahankan kefilosofisannya. Gaya arsitekturnya pun bercorak ala Jawa; ada bedug sebagai alat untuk penanda adzan tiba, jam, seni pahat pada kayu-kayu penyangga maupun jendela dan pintu masjid. Masjid bercorak seperti ini bisa diketemukan yang mana pada waktu itu masjid bersinggungan langsung dengan proses penyebaran Islam atau karena kedekatannya dengan pusat pemerintahan Jawa. Ketika arsitektur Jawa diadopsi oleh beberapa daerah lain, hanya mempraktikkan pada gaya limasan atap masjid, bedug dan menara masjid.

Pulau Jawa sendiri merupakan daerah pusat penyebaran Islam yang dibawa oleh Walisongo. Di mana bangunan-bangunan peninggalannya yang telah menyejarah patut untuk dijaga dan dilestarikan. Dalam hal ini seperti bangunan masjid dengan arsitektur yang unik yakni perpaduan antara Islam dan nuansa kejawaan. Terutama masjid yang masih mempunyai hubungan dengan proses Islamisasi tanah Jawa dan masih ada kaitan 
dengan beberapa keraton dan kedinastian di Jawa. Misalnya masjid Demak, masjid Kudus. Dalam hal ini penulis akan ulas arsitektur masjid di Jawa dengan fokus pada arsitektur masjid kuno/klasik.

\section{Perkembangan Arsitektur Islam}

Dalam karya arsitektur Islam, ternyata tampak segala macam hal yang melatarbelakangi penampilannya. Apakah itu berupa cara penerapan ungkapan setelah terjadi perpaduan yang disebabkan masuknya kehidupan baru Islam, apakah itu merupakan kejadian dalam sebuah pengalaman selama perjalanan perkembangan Islam maupun hal-hal yang ditemukan sebagai keterampilan baru sehubungan dengan aktivitasnya sebagai manusia yang berbudaya. Bagaimanapun alasannya bahwa penampilan arsitektur Islam ternyata merupakan milik hakiki dari kebudayaan baru berdasarkan ajaran Islam.

Pertama, penampilan bangunan masjid sebagai amanat yang diperintahkan Tuhan sebagai tempat peribadatan kaum Muslimin. Masjid tersebut kemudian menjelma dengan penuh dedikasi, yang pola dasar konstruksinya-baik fisik maupun non-fisik, terus berubah sampai sekarang. Dampak daripada perkembangan Islam, maka masjid menjadi pedoman pembuatan bangunan-bangunan di luar masjid yang merupakan fasilitas untuk menampung segala kegiatan manusia. Dari hal ini dapat dikatakan bahwa arsitektur Islam terdiri dari bangunan religi dan non-religi. Dalam perkembangannya muncul berbagai kelengkapan unsur penambahan keindahan yang berupa hiasan dan alat perlengkapan.

Dalam perkembangan berikutnya, arsitektur Islam tampil yang terpadu dengan unsurunsur tradisi daerah, yang kemudian menjadi bentuk unik sebagai ciri penampilan masjid dan bangunan lainnya. Hal ini adalah bentuk-bentuk lengkung dan kubah yang jelas merupakan kekhususan daerah yang masuk menjadi bagian dari arsitektur Islam. Gaya arsitektur religi ini sering digunakan dalam masjid-masjid kebanyakan di Indonesia. Selanjutnya kemudian muncul penampilan gaya dekoratif-ornamentik yang senantiasa menjadi bagian penting dari kehadiran masjid dan bangunan lainnya, sehingga belum lengkap apabila arsitektur Islam tanpa ornamen dan dekorasi. Dari kesan dekoratifornamentik ini, kita dapat melihat kehidupan kaum Muslim pada saat itu. Pengaruh lingkungan alam yang kemudian menjadi hiasan yang terpatri dalam ornamen-ornamen berhias tumbuh-tumbuhan.(Rochym, 1983, p. 17).

Berbagai gaya dan corak menyemarakkan penampilan bangunan-bangunan arsitektur Islam secara mewah dan megah. Hal itulah yang merupakan ungkapan sebagai nilai-nilai tertinggi dari kemampuan kaum Muslim dalam menampilkan rasa dan gerak hati yang telah mendapatkan dasar ajaran Islam. Tentu saja bangunan masjid adalah yang utama untuk mendapat perhatian. Hitti mencatat bahwa bagi kalangan Islam seni merupakan capaian 
tertinggi dalam arsitektur religi. Para arsitekt Islam atau orang-orang yang mereka pakai dalam mengembangkan bangunan yang sederhana berdasarkan contoh-contoh yang sudah ada, akan tetapi dengan tegas sekali membayangkan spirit dari agama Islam. bangunan itu adalah masjid yang telah dapat mengikat berbagai bangsa dan bersifat internasional.(Hitti, 2008, p. 105).

Masjid adalah contoh yang tertinggi dari wujud kerjasama dan toleransi dalam kebudayaan antara Islam dan tradisi daerah. Perkembangan awal ini penulis gambarkan dalam arsitekturnya dan kemudian akan berlanjut pada fungsinya. Masjid dalam arus perkembangannya dalam arsitekturnya, tidak lepas dari pengaruh konstruksi dari kearifan lokal, lingkungan atau wilayah setempat. Membicarakan kearifan lokal berarti juga membicarakan entitas yang sangat menentukan harkat dan martabat manusia dalam komunitasnya. Hal itu berarti bahwa kearifan lokal yang di dalamnya berisi unsur-unsur kecerdasan kreatifitas dan pengetahuan lokal pada arsitektur masjid klasik di Jawa yang merupakan manifestasi dari kebudayaan dan peradaban Islam yang ada di Jawa.(Zaki, 2017, p. 88).

Masjid tempo dulu di Jawa abad 15 dan 16 M, mempunyai bentuk yang sangat khas. Arsitektur pada abad tersebut merupakan arsitektur transisi dari gaya Jawa Hindu-Budha ke gaya Jawa Islam. Masa transmisi tersebut Islam menjejakkan peninggalan historis berupa masjid yang berpadu dengan kerangka lokalitas. Masjid sebagai tempat ibadah kaum Muslim, tentunya sangat erat hubungannya dengan awal masuk dan berkembangnya Islam di Nusantara. Perkembangan selanjutnya, terutama dalam fungsi bahwa peran masjid sebagai pusat dakwah Islam mampu diterima oleh masyarakt Indonesia tanpa kekerasan, perkelahian atau perang. Kebijakan pada sosok Walisongo melalui desain bangunan masjid yang menyelaraskan model bangunan lokal dan menghargai kesucian tempat-tempat peribadatan lama, berhasil memikat hati masyarakat. Bahkan, dengan memanfaatkan bangunan masjid secara optimal, para wali di Jawa, misalnya berhasil menyiapkan sistem pemerintahan Kerajaan Demak, sehingga sampai pada akhirnya pimpinan Demak dapat diislamkan dan Demak menjadi kerajaan dengan sistem pemerintahan Islam pertama di Jawa.(Hakim, 2011, p. 212).

Menelisik sejenak persinggungan ilmu pengetahuan dan arsitektur dalam peradaban Islam dunia. Arsitektur mengembangkan dirinya untuk memenuhi kebutuhan fisik dan metafisik, untuk memenuhi unsur fisik dan psikologis masyarakat. Keindahan bentuk arsitektur merespon keinginan emosional dan intelektual serta mengarah pada kontemplasi. Bentuk arsitektur bangunan merupakan rajut makna dari referensi dasar mitologis, ritual hingga doktrinal. Melihat bentuk arsitektur dapat dipahami sebagai kerangka bagaimana konsep tradisi itu berlaku dalam masyarakat nyata. Melintas jembatan intelektual, 
arsitektur menjadi pintu masuk ke ide abstrak kehidupan. Sepanjang zaman di berbagai tempat, pemahaman arsitektur selalu naik turun di antara dua kecenderungan, bobot pertimbangan keindahan dan seni atau pertimbangan kehendak dan pengetahuan.

Memasuki abad-abad pengetahuan dimulai di sekitaran abad ke-19, ketika seni terapan mulai dikenal, porsi pertimbangan akal mulai menggejala. Bahkan di abad pertengahan dan Renaissans ketika pengetahuan dirujuk pada batasan geometris, teori, juga beberapa pemahaman bagian-bagian arsitektur mulai didekati dengan matematis. Bibit pemahaman pendekatan secara matematis bahkan telah diperkenalkan oleh Plato di sekitaran tahun 350 SM ketika menyatakan dalam kanun ajarannya, Timaeus, bahwa keindahan akan sepenuhnya dicapai lewat kesempurnaan proporsi. Plato dan Phytagoras membuahkan tafsir keindahan sejati (Golden Mean), yakni semacam rahasia suci gugusan angka dalam membentuk proporsi. Phi merupakan inti dari filosofi angka suci yang menentukan kualitas magis dari susunan tersebut.(Fanani, 2009, p. 12).

Para arsitek yang mempertimbangkan dampak dari ukuran bangunan terhadap situasi kejiwaan seseorang atau masyarakat yang berada di dekatnya, mulai menciptakan alat pendekatan yakni kaidah-kaidah tata bangunan mengenai skala ukuran satu bagian bangunan, proporsi perbandingan satu bagian dengan bagian lain, pola, susunan antarbagian, maupun irama, yang mengatur penggabungan pola. Arsitek perlu mempertimbangkan skala manusiawi ketika membangun rumah tinggal, pun juga masjid yang penuh pertimbangan banyak orang baik konsep maupun tradisi setempat. Arsitektur mencerminkan tingkat penguasaan masyarakat terhadap pengetahuan. Masyarakat yang masih dikuasai oleh alam akan cenderung menerima bentuk-bentuk dan bahan-bahan yang murni dan alami. Sementara masyarakat yang mulai mengembangkan teknologi untuk mengatasi alam cenderung pula pada bahan dan bentuk turunan alam maupun olahan mereka sendiri.

Fanani menggambarkan karya arsitektur sebagai salah satu wujud paling konkret dari kebudayaan, sebagai bagian dari kebudayaan fisik yang sifatnya nyata berupa benda-benda yang nampak. Dengan kata lain, apabila menyikapi arsitektur sebagai artefak budaya maka mencermati secara terperinci bagian-bagiannya akan menjadikannya sebagai tanda-tanda untuk memandu penelusuran kaitannya pada kompleksitas unsur kebudayaan di mana di berada. Ia lebih jauh menyatakan bahwa penelusuran lebih mendalam akan sampai pada jalinan sistemik yang utuh sehingga keberadaan karya arsitektur sulit dipisahkan dari dua bentuk kebudayaan yang lahir, yaitu sistem sosial dan kompleks gagasan.(Fanani, 2009, p. 18).

Konsep karya arsitektur yang utuh tidak hanya didasarkan pada perhitungan matematis dari kebutuhan kuantitatif penggunanya, tetapi juga mengacu pada 
pengembangan citra kehidupan, tindakan, pola pikir, termasuk pemahaman keyakinan agama. Sebuah karya arsitektur barulah menjadi bermakna ketika fungsi-fungsi yang dikandungnya, baik fungsi fisik indrawi maupun fungsi non-fisiknya dapat dikordinasikan secara terpadu, dan tidak ditangkap secara terpisah-pisah. Dengan demikian, semua kaitan erat antara gagasan kehidupan, perilaku masyarakat, dan posisi menampilkan benda-benda budaya sekaligus dalam suatu sistem yang terintegrasi menjadi jelas.

Melalui arsitektur, dalam hal ini arsitektur masjid dapat ditelusuri sampai pada keadaan masyarakat Muslim, situasi sosialnya, pemahaman keagamaannya, pada waktu dan tempat di mana karya arsitektur masjid tersebut berada. Arsitektur masjid sebagai objek yang terbentuk dengan sendirinya akan mampu memberikan penjelasan tentang pola prilaku, keinginan, dan pemikiran keagamaan masyarakat Muslim di sekitar masjid. Menara, kubah, kaligrafi, sika, maksura, semua bisa menjadi tanda untuk mengungkap rangkaian peristiwa.

Kebudayaan Islam ketika itu berani mengadopsi sejumlah atribut budaya dari wilayah yang dikuasainya tanpa harus meninggalkan esensi budayanya sendiri. Ekspedisi umat Islam dalam memperkenalkan Islam kepada masyarakat luas di luar wilayah pusat sejak pasca Perjanjian Hudaibiah dan terutama setelah wilayah Syam (Damaskus), Qadisiah (Persia), dan Fustat (Mesir) mulai merambah, memberikan pengalaman baru yang memperkaya tampilan arsitektur bangunan. Dari wilayah Damaskus hingga wilayah di sekitar Laut Mediterania Islam menerima berbagai elemen arsitektur gaya Greco Roman dalam pengaruh Hillenistik. Wilayah Mesir memberi sumbangan dari khazanah lembah Sungai Nil yang telah bersentuhan dengan tradisi Romawi.(Fanani, 2009, p. 29).

Masjid Agung Damaskus adalah salah satu contoh bagaimana umat Kristiani mengubah bangunan Kuil Yupiter dari tradisi Romawi menjadi gereja, kemudian ketika kaum Muslim menguasai wilayah itu menjadikannya sebagai masjid. Demikian juga dengan tradisi raga, hias dekoratifnya, Masjid Agung Damaskus memanfaatkan lukisan dinding flora natural dari tradisi gaya Byzantium. Pengaruh tradisi bangunan Kristiani juga tampak pada tampilan bangunan Kubah Al-Sakhra (Dome of The Rock atau al-Quds) Palestina. Bentuk rotunda mengingatkan pada bentuk rotunda gereja-gereja yang berkembang di wilayah Syiria sejak 400 M. Kaum Muslim menerima warisan konsep basilika bagi sebuah rumah ibadah. Konsep basilika sendiri telah dikembangkan umat Kristiani yang mengambilnya dari tradisi bangunan pertemuan umum bangsa Romawi, dipakai guna keperluan membangun gereja. Secara cerdik kaum Muslim memanfaatkannya pula dan menerapkannya bagi bangunan masjid. Mihrab juga diwariskan oleh tradisi Kristen Koptik dalam menandai tempat-tempat penting di ruang dalam gereja mereka. Ini menyiratkan betapa dalam 
persoalan akidah terdapat perbedaan yang sangat nyata, namun dalam pergaulan budaya hubungan itu begitu lentur.(Fanani, 2009, p. 31).

Demikian pula di Nusantara pada masa lalu. Ulama-ulama yang menyebarkan Islam di Nusantara dengan bijaksana tidak membangun masjid dengan desain arsitektur layaknya Timur Tengah atau negeri Arabia. Tetapi menggunakan desain arsitektur setempat yang pada waktu itu sudah ada di Nusantara.(Putra Mahardi, 2021). Agus Sunyoto mencatat desain masjid dengan atap susun tiga di Jawa adalah adopsi dari langgar Kapitayan di tanah Sunda disebut juga dengan Sunda Wiwitan). Tentu saja dengan penyesuaian filosofi-filosofi keislaman. Misalnya masjid dengan atap susun tiga dimaknai sebagai representasi dari Iman, Islam, Ihsan. Sehingga dalam sebuah bentuk tidak ada pekem tertentu dan khusus dalam membuat masjid. Yang sebenarnya bentuk masjid yang berbeda-beda itu mencirikhaskan kedaerah dan lokalitas masing-masing wilayah maupun negara. Dan inilah merupakan dialog antara ajaran Islam dengan kebudayaan lokal yang bersinggungan langsung membentuk dan membangun sebuah peradaban bersama berupa karya nyata dalam arsitektur masjid di Indonesia.(Sunyoto, 2012, p. 450).

Perkembangan selanjutnya, masjid mampu menjadi simbol kebudayaan dari kota-kota kerajaan Islam di Nusantara. Dalam planologi kota-kota kuno di Jawa, pada umumnya tidak meninggalkan masjid sebagai elemen penting di dalamnya. Masjid menjadi elemen yang digunakan dalam pembangunan perkotaan, seperti di Cirebon, Demak, Semarang, Yogyakarta dan daerah lainnya yang pernah menjadi pusat peradaban kerajaan Islam di Jawa. Hal ini menunjukkan bahwa fungsi masjid dalam perjalanan perkembangan budaya masyarakat menempati posisi penting sebagai bagian yang tidak terpisahkan dari sistem pemerintahan dan kosmologi masyarakat Indonesia, khususnya Jawa. Kedudukan penting masjid dalam perkembangan budaya, peradaban dan ilmu pengetahuan nampak perlu mendapat perhatian dari semua pihak. Masjid dalam tinjauan sejarah bukan hanya sekadar bangunan tanpa makna. Namun, banyak nilai filosofis penting yang ada pada masjid, yang sangat bermanfaat bagi perkembangan peradaban manusia. Masjid berperan dalam penulisan sejarah peradaban dan ia merupakan salah satu saksi di era lain kejayaan peradaban kemajuan ilmu pengetahuan.(Hakim, 2011, p. 213).

\section{Arsitektur Masjid Klasik Di Jawa}

Arsitektur masjid yang tergolong pada kekunoan/klasik ialah masjid yang masih menggunakan gaya atap limasan, adanya bedug dan bisa juga menara. Dalam penelitiannya Wuri Handoko menjelaskan bahwa di Maluku selalu dijumpai masjid-masjid kuno, baik yang masih utuh atau yang hanya tinggal sekadar cerita masa lalu. Sebab, banyak wajah masjid yang sudah sangat berubah menjadi masjid modetn, bahkan ciri kekunoannya sudah hilang sama sekali. Tapi, bagaimanapun, masjid kuno/klasik merupakan penanda paling utama 
dalam sebuah wilayah yang telah mendapat pengaruh Islam lebih dulu. Dengan demikian, masjid menjadi salah satu data yang spesifik yang menggambarkan cara Islam dalam menyiarkan agamanya di berbagai daerah.(Handoko, 2013, p. 31).

Ini pun berlaku pada daerah lain, termasuk di Jawa. Dalam proses penyebarannya menggunakan cara yang spesifik yang berbentuk masjid. Seperti misalnya masjid Kudus, masjid yang sebelah kiri itu merupakan menara yang didirikan oleh Sunan Kudus sebagai penanda masjid yang menirukan gaya arsitektur kuno masa kerajaan Hindu-Budha, yang kemudian dalam perkembangannya di sebelah kanan berdirilah masjid Al-Aqsa. Juga pada masjid Demak, Jawa Tengah, yang mana masjid ini merupakan masjid yang didirikan oleh Raden Fatah yang merupakan putera dari Raja Brawijaya V dari Dinasti Majapahit. Sehingga kita bisa lihat sendiri, seperti masjid Demak yang berdiri kokoh hingga saat ini, kita bisa lihat keindahan ornamen, arsitektur khas Jawa dan Cina memadu dalam bangunan yang bersejarah tersebut sejak abad 14 (era walisongo). itu merupakan masjid yang memadukan antara arsitektur Jawa, Cina menjadi masjid yang unik dan menarik hingga abad ini.

Peranan para wali dan raja-raja Jawa sejak Raden Patah di Demak sampai Mataram Jawa Tengah sangat besar artinya bagi penyebaran dan pengembangan agama dan kebudayaan Islam di Jawa dan sekitarnya. Namun, potensi luar biasa ini lambat laun memudar dengan semakin dalamnya pengaruh kekuatan kolonial Belanda (VOC) yang memiliki latar belakang budaya dan agama yang berbeda. Para pemimpin yang berkuasa di Jawa Timur mempertahankan tradisi pola perkotaan yang berakar pada tradisi Pajang dan Mataram, meskipun di beberapa kota terpaksa menyesuaikan dengan kondisi daerah. Di kawasan ini dibangun masjid agung atau jami' dengan skala kota yang terletak di pusat kota.

Arsitektur masjid Jawa (klasik) dikenal dengan tampilannya yang unik nan klasik, misalnya tipe tajug limasan dalam masjid. Penampilan tipe ini memang memiliki kekhasan, yakni atapnya berbentuk limas, secara falsafah memiliki arti keterkaitan. Mengenai jenis bangunan ini berasal dari kata Taju' yang berarti mahkota yang populer dengan istilah tajuk/tajug. Berkaitan dengan hirarki bentuk ruang masjid kemungkinan masjid Jawa mengadopsi ruang ndalem yang ada dalam khazanah arsitektur rumah tradisional Jawa.(Akbar, 2021).

Masjid-masjid kuno di Indonesia pada umumnya mempunyai ciri khas tersendiri dibandingkan dengan masjid-masjid yang ada di negara lainnya. Arsitektur masjid di Indonesia beragam, tidak ada suatu rancangan atau pola tertentu yang mengikat. Sementara hampir semua peminat kajian sejarah Jawa akan berpendapat bahwa masjid-masjid kuno yang tersebar di Indonesia dipengaruhi kebudayaan Hindu-Budha yang menyerupai arsitektur candi, yakni atapnya dibuat bertingkat yang meruncing ke atas. 
Perkembangan arsitektur masjid dalam transformasi bentuk, ruang dan fungsi memiliki perkembangan yang beragam. Terkait dengan fungsi utama masjid adalah sebagai tempat peribadatan, khususnya shalat wajib lima waktu. Banyaknya ayat al-Quran dan Hadis yang membicarakan tentang masjid, menunjukkan bahwa masjid menempati posisi penting dan strategis sebagai tempat dan pusat peribadatan umat Islam. Hal ini sejalan dengan perkembangan Islam yang dibawa Nabi Muhammad SAW di Arabia sejak 600 M yang meluas baik ke Barat maupun ke Timur. Kehadiran Islam telah memberikan budaya baru di masyarakat dunia. Produk budayanya dapat dilihat dalam berbagai manifestasinya, termasuk arsitektur.(Rochym, 1983, p. 42).

Terbukti, masjid telah menjadi sebuah karya arsitektur yang merupakan hadil kebudayaan terbesar umat Islam, baik dari segi persebaran geografis, ragam bentuk ukuran sepanjang masa. Fakta ini semakin berkembang, karena arsitektur masjid secara simultan mengandung dua unsur, yaitu sebagai kristalisasi nilai dan pandangan hidup masyarakat Muslim, dan sekaligus sebagai wujud manusia sesuai dengan nilai-nilai tersebut, dan pandangan masyarakat tentang kehidupan itu sendiri. Oleh karena itu, dapat dipahami masjid merupakan pusat budaya keagamaan Islam, bahkan merupakan tanda, simbol, dan orientasi bagi eksistensi Islam dan ummatnya. Dari segi fungsi, seiring dengan masuk dan berkembangnya Islam di Pulau Jawa, masjid dalam perkembangannya tidak hanya digunakan sebagai tempat ibadah dalam arti sujud. Namun, juga menjadi tempat pembinaan, pengajaran, praktik sosial, keamanan dan benteng bagi umat Islam. Kekayaan arsitektur tradisional bangsa Indonesia cukup kuat sebagai landasan utama, seperti hal nya bentuk-bentuk bangunan masjid pada saat awal mula didirikanya. Seperti di mana wujudwujud arsitekturnya dengan ciri khas seperti atap berundak dan dengan makna filosofisnya.

Banyak masjid yang dihormati di Indonesia masih mempertahankan bentuk aslinya, menyerupai kuil Hindu atau Budha dan bahkan Pagoda. Arsitekturnya mengadopsi banyak bentuk dari Timur Tengah seperti atap, kubah, dan ornamen. Di masa lalu, masjid di Jawa memiliki bentuk yang mirip dengan arsitektur candi. Hal ini disebabkan adanya akulturasi budaya antara budaya lokal dan asing. Ciri masjid kuno yang telah menerima akulturasi budaya adalah sebagai berikut pertama, atapnya berbentuk tumpang tindih yang semakin mengecil dan membentuk limas. Kedua, tidak ada menara tetapi dilengkapi dengan gendang atau bedug untuk peringatan masuk waktu adzan. Ketiga, Letaknya berada di sekitar istana atau di tempat-tempat keramat seperti bukit atau makam.

\section{Integrasi Islam dan Kebudayaan pada Seni Arsitektur Masjid di Jawa}

Islam merupakan agama universal dan eternal serta sempurna, yang diturunkan oleh Allah guna memberikan petunjuk dan rahmat bagi umat manusia untuk menjalankan fungsinya dalam kehidupan guna memperoleh kebahagiaan hidup di dunia dan di akhirat. 
Dalam perspektif Islam, pernan manusia tidak lain adalah sebagai khalifatullah di muka bumi yang bertugas untuk mewujudkan pesan Islam yaitu rahmatan lil 'alamin yang senantiasa harus beribadah kepada-Nya. Maupun dalam arti luasnya, sebagai aktivitas batin dan fisik manusia dalam rangka berhubungan dengan Allah, dengan manusia dan dengan alam semesta. (Ismail, 2017, p. 37; M. Asy’ari, 2007, p. 169).

Kebudayaan dalam kisah sehari-hari dibatasi hanya pada hal-hal yang indah (seperti candi, tarian-tarian, seni rupa, seni suara, kesusasteraan) saja. Sedangkan dalam konsep antropologi bahwa kebudayaan adalah keseluruhan sistem gagasan, tindakan, dan karya manusia dalam kehidupan bermasyarakat yang dijadikan manusia dengan belajar. Dalam kebudayaan terdapat kebudayaan universal, yang meliputi bidang sosial, politik, ekonomi, ilmu pengetahuan dan teknologi, filsafat dan seni. Dengan demikian, setidaknya seni juga mendapat perhatian dalam Islam. Sidi Gazalba dalam Asy'ari mencatat seni merupakan perwujudan kebudayaan manusia yang memenuhi syarat etis. Inti dari seni adalah usaha untuk menciptakan bentuk-bentuk yang menyenangkan, indah, baik dalam bidang seni sastra, musik, tari, rupa maupun drama. Selain seni yang telah disebutkan, kesenian dalam artikel ini akan fokus pada seni arsitektur masjid, terutama di Jawa. Terutama yang paling penting, persinggungan antara Islam dan kesenian dalam arsitektur masjid di Jawa. Kalau dalam Koentjoronigrat adanya perubahan dalam kebudayaan yang membuat perkembangan manusia. (Koentjaraningrat, 1990, 2015, p. 144; M. Asy’ari, 2007, p. 170).

Kehadiran arsitektur Nusantara pada suatu daerah dapat menunjukkan atau menampilkan ciri khas dari daerah tersebut. Arsitektur Nusantara telah menempatkan diri menjadi salah satu kekayaan jati diri anak bangsa Nusantara dan jati diri ini sudah dinyatakan jauh sebelum sebutan Indonesia sendiri muncul. Prinsip dasar arsitektur Nusantara yaitu, pertama, arsitektur Nusantara merupakan sebuah pernyataan yang kemanusiaan dan arsitektur menempatkan dirinya sebagai salah satu pernyataan yang mengandung beribu gambaran dan persepsi. Nusantara merupakan tempat yang luas, terdiri dari berbagai macam pulau dan penduduknya yang mempunyai beragam kebudayaan. Kedua, belajar tentang arsitektur Nusantara adalah bagaimana mempelajari keberagaman atau ke-Bhineka Tunggal Ika-an dalam sebuah kacamata atau dalam kebersatuan. Mempelajari tidak hanya dari fisiknya saja, tetapi mengerti dalam sebuah pemahaman yang hakiki, berbicara tentang dasar, prinsip dan pedoman.(Hikmah et al., 2020, p. 72).

Handoko menguraikan, faktor budaya, di antara banyak definisi tentang kebudayaan, meliputi aspek falsafah, kognisi lingkungan, persepsi, norma dan religi, struktur sosialkeluarga dan ekonomi. Dalam hal ini, objek materi yang dikaji ialah masjid, sehingga uraian masjid menjadi bagian dari bangunan yang berkebudayaan dan berfalsafah. Masjid 
merupakan pusat kegiatan peribdatan umat Islam, yang bersumber dari keseluruhan kemampuan masyarakat. Masjid merupakan representasi umat Islam yang melahirkan dan mensejahterakan mereka. Pada awal prosesnya, perkembangan Islam tidak secara signifikan memperkenalkan tradisi arsitektur yang benar-benar baru, tetapi memuat adaptasi terhadap tradisi kodifikasi budaya Hindu-Budha. Hal ini terutama terlihat di Jawa, akomodasi antara tradisi arsitektur pra-Islam dan Islam masih sangat jelas terlihat di beberapa masjid, beberapa di antaranya dibangun dari sisa-sisa arsitektur Hindu-Budha saat itu. Misalnya sepeti bangunan bertingkat pada atap tumpang atau bersusun, atau ketika ditelusuri lebih jauh lagi bentuk puden berundak yang mencerminkan kebudayaan megalitik masa prasejarah yang dapat dikenal di berbagai tempat di tanah air. Dan ini nampak hampir ada pada masjid-masjid di Jawa yang masih menggunakan arsitektur kuno dalam bangunannya. (Handoko, 2013, p. 42).

Dengan demikian, jika merujuk ungkapan Uka, keberadaan Islam di Nusantara dapat mencerminkan kemungkinan keberlanjutan budaya dan religi masa prasejarah, terutama budaya dan religi masa megalitik yang terus berlanjut hingga masa Islam datang ke Nusantara. Dalam banyak aspek, Islam dapat ditelisik karakteristiknya bagaimana persentuhannya dengan budaya dan agama yang sudah ada jauh sebelumnya, baik Hindu, Buddha, maupun Animisme-Dinamisme. Hal ini kemungkinan menjadi salah satu alasan keselarasan Islam terhadap budaya lokal yang telah tumbuh sebelumnya, dan terus eksis di masyarakat saat ini, yang pada umumnya masih menghormati dan mempertahankan tradisi lokal.(Tjandrasasmita, 2009, p. 240). Misalnya menjelaskan pengalihan Demak ke Pajang yang kemudian disusul dengan berdirinya kerajaan Islam Mataram yang menjadi cikal bakal wilayah Yogyakarta. Moment Islamisasi yang signifikan dengan ditunjukkan dari Jawa pesisiran utara menuju wilayah pedalaman wilayah tengah.

Pemindahan pusat kerajaan Islam di Mataram sangat mempengaruhi kebijakan sultan dalam mengambil keputusan untuk mendapatkan legitimasi dari masyarakat yang masih mayoritas beragama Hindu-Budha. Sebagai pewaris tradisi Mataram dalam pembangunan masjid, tentunya masih dipengaruhi oleh tradisi yang dibawa oleh raja-raja Jawa sebelumnya. Puncak terbentuknya budaya Jawa saat ini adalah ketika Sultan Agung memimpin Kesultanan Mataram. Kebijakan Sultan mengadopsi tradisi-tradisi Islam sebagai bagian tradisi kerajaan juga menguatkan posisi Islam di tengah kebudayaan lama HinduBudha. Ini terlihat juga, ketika Sultan Agung berkuasa, ia menggunakan gelar Senapati Ing Alaga Ngabdurrahman Sayidin Panatagama Kalipatullah, yang mana gelar ini perpaduan antara nama Jawa dan Islam. Bahkan, Sultan Agung, mengkombinasikan ajaran Islam dengan budaya Jawa yang banyak dipengaruhi oleh kepercayaan Anismisme, Hindu, Budha, yaitu kalender Jawa, termasuk berdirinya masjid Pakualaman di Yogyakarta menjadi 
salah satu perkembangan peradaban Islam Jawa yang begitu banyak pertemuannya juga dengan budaya Jawa.(Hakim, 2011, p. 222; Sutiyono, 2010, p. 74).

Adityaningrum dalam penelitiannya pada Masjid Agung Surakarta mencatat bahwa unsur-unsur Islam sudah menjadi sinkretik dengan unsur-unsur arsitektur tradisional Jawa, sehingga makna yang terkandung dalam arsitektur masjid juga menunjukkan adanya keterpaduan dua unsur tersebut.(Adityaningrum et al., 2020, p. 56). Di dalam berdirinya masjid juga terdapat nilai-nilai budaya, apalagi masjid itu masjid yang telah lama berdiri dengan arsitektur kuno, pasti menyimpan makna budaya fisik dan non-fisik. Budaya fisik (aristektur masjid), yang mana arsitektur masjid sangat terpengaruhi dengan gaya-gaya transmisi Hindu-Budha atau gaya tradisional. Bahkan ketika masa walisongo sampai saat ini ada beberapa masjid yang masih mempertahankan bentuk masjid itu, misalnya di Kudus, Demak, dan masih banyak lagi, terutama juga masa kerajaan-kerajaan Islam di Jawa. Namun, budaya non-fisik (tradisi), masjid yang berdiri di lokal, kadang masih menyimpan kebiasaan untuk menyambut bulan-bulan yang suci dengan acara-acara kendurian, pengajian, slametan. Abror menjelaskan dalam penelitiannya pada Masjid Pathok Negoro bahwa terdapat nilai budaya dalam masjid, misalnya Mustaka, Atap Tumpang, Kolam, Beduk, Lawang Endek, Saka Kayu Jati, Gapura, Undak-Undak, Makam. Dan setiap itu juga mempunyai makna simbolik pada masjid tersebut (Abror, 2016, p. 72).

Integrasi antara Islam dan seni arsitektur Jawa tidak pernah lepas dari peran penting para ulama penyebar Islam di tanah Jawa. Akulturasi antara Islam dan budaya setempat menghasilkan nuansa karya yang indah, termasuk arsitektur pada masjid. Meskipun banyak yang mencoba memperdebatkan antara persinggungan antara Islam dan budaya. Intinya kalau itu tidak bertentangan dengan syariat Islam (ushul), tidak masalah, toh juga semakin menunjukkan nuansa berislamnya sesuai realitas di Indonesia. Misalnya, bersarung, baju batik, bahkan sarung batik, banyak yang mengideal kan Islam layaknya Islam Arabia, tapi kurang melihat realitas yang ada bahwa kita juga sebagai Muslim yang realitas. Pun ini selaras dengan konteks seni arsitektur masjid di Jawa ini. Masjid yang dibangun dengan tujuan sebagai ibadah, kegiatan keislaman. Namun, dalam coraknya menampilkan nuansa budaya lokal, seni arsitektur lokal yang tertempel menghiasi pada masjid. Karena memang masjid di Jawa itu tidak lepas dari pusat pemerintahan pada waktu itu. Infiltrasi kebudayaan Jawa kuno juga nampak jelas pada mustaka masjid yang masih bertahan sampai saat ini di beberapa masjid kuno yang ada di Jawa.

Integrasi antara Islam dan budaya setempat, terutama seni arsitektur dalam masjid, dalam kacamata penulis tidak begitu dipermasalahkan. Islam itu agama yang melintas batas, tidak terpetakkan dengan lokasi geografis, sehingga konteks keberislamannya pun beragam, tidak lain di Indonesia. Terutama persinggungan antara Islam dan budaya. Budaya 
merupakan produk manusia di manapun tempatnya, sedangkan agama produk Tuhan, sehingga keduanya jangan dibenturkan karena berbeda, dipastikan akan melahirkan konflik. Maka, budaya di Nusantara yang begitu beragam, maknailah dengan cara Islam yang indah. Misalnya akulturasi/integrasi seni arsitektur Islam dengan Jawa berpadu pada sebuah bangunan, ini akan menambah kekayaan arsitektur dalam Islam lokal sendiri. Semua tidak salah, konsep bangunan masjid dengan gaya Pagoda, Kelenteng, Rumah adat, Joglo, semua tidak salah, disini akan menambah nilai estetis lokal. Yang terpenting tujuan awal masjid berdiri tetap sebagai tempat ibadah dan adapun tujuan lain itu nanti.

Kemudian muncul pertanyaan, mengapa arsitektur masjid di Jawa bisa berbeda? Ditelisik dalam kesejarahan agama-agama di Indonesia, bahwa agama Hindu-Budha menjadi agama yang cukup tua menghuni di negeri ini. nuansa yang kemudian di bangun oleh Islam kala itu ialah menyesuaikan tempat. Peradaban yang dibangun pun sama, sebuah tradisi yang tumbuh sama, sehingga kebudayaan dalam bentuk seni ruang arsitektur pun sama, yakni adanya akulturasi antara Islam dan budaya lokal, budaya lokal yang terhiasi dengan agama-agama atau kepercayaan yang telah lahir dahulu di Indonesia, khususnya Jawa. Mengapa kemudian beda? Arsitektur masjid di Jawa berbeda dengan gaya arsitektur Timur Tengah atau Arab. Ini bukan soal salah menyalahkan, melainkan integrasi antara Islam dan kebudayaan setempat akan melahirkan kekayaan khazanah dalam realitas Islam. Sehingga masjid yang berdiri di Jawa ini, bisa menggunakan gaya arsitektur Jawa, bahkan ada yang masih mempertahankan masjid dengan nuansa arsitektur Hindu-Budha.

Sebelum agama Islam masuk dan berkembang di Indonesia, Indonesia sendiri sudah memiliki kebudayaan yang dipengaruhi oleh agama Hindu dan Buddha. Dengan masuknya agama Islam, maka Indonesia mengalami proses akulturasi yang melahirkan kebudayaan Islam. Namun, dengan adanya kebudayaan baru yaitu Islam, tidak berarti menghilangkan kebudayaan lama yang telah ada. Tetapi semakin berwarna karena adanya akulturasi budaya tersebut. Dan itu tidak bertentangan dengan Islam itu sendiri. Arsitektur yang menghiasi indahnya masjid dengan gaya arsitektur Jawa, tidak menghilangkan identitas Islam. arsitektur hanya penghias dalam masjid saja, ketika peribadatan berlangsung, pun semua sama. Meskipun, adat tradisi dalam pelaksanaan ketika di Indonesia disguhkan dengan nuansa kultural, itulah Islam Indonesia.

\section{Kesimpulan}

Integrasi Islam dan kebudayaan menghasilkan sebuah rumusan indah dalam berislam. Umat Islam di Indonesia dihadapkan dua pandangan yang harus bisa disiasati, yakni menjadi Muslim yang idealitas dan Muslim yang realitas. Kebudayaan di dalamnya terdapat kesenian yang adapun kesenian begitu banyak contoh kongkritnya. Misalnya masjid dan 
seni arsitekturnya yang menggunakan seni arsitektur lokal. Ini sebuah tanda yang khas dan unik pada masyarakat Muslim Indonesia. Membangun peradaban Islam yakni dengan konteks, realitas yang ada. Misalnya pada pembangunan masjid yang bergaya arsitektur Jawa. Identitas keislaman ala Indonesia begitu nampak, dan ini tidak bertentangan dengan syariat Islam dalam mengerjakan peribadat wajib kepada Tuhan.

Identitas Muslim Indonesia selain berbusana, dalam seni tata ruang pun juga mempunyai identitas seperti masjid misalnya. Masjid sebagai poros kegiatan umat Islam dalam hal apapun, telah bertransformasi selain fisiknya, tapi juga tujuan berdirinya masjid tersebut. Jawa begitu kuat dengan falsafahnya, sehingga masjid sebagai konstruk Islam yang terlihat, pun termaknai dengan falsafah Jawa. Ini nampak pada atap masjid yang berpunden/bertingkat dan mengerucut ke atas. Bahkan ada arsitektur masjid engan gaya rumah joglo, masjid dengan gaya rumah Minang, masjid dengan gaya Pagoda, masjid dengan gaya Klenteng. Ini menandakan akulturasi Islam dan budaya tidak bisa terpisahkan. Dan ini tidak juga menyalahi kodrat sebagai Islam yang sejati, Islam yang sejati itu terletak pada hati dan jiwa masing-masing umat.

\section{Referensi}

Abror, I. (2016). Aktualisasi Nilai-Nilai Budaya Masjid Pathok Negoro. Esensia: Jurnal ImuIlmu Ushuluddin, 17(1). https://doi.org/DOI: https://doi.org/10.14421/esensia.v17i1.1279.

Adityaningrum, D., Srimuda Pitani, T., \& Setyaningsih, W. (2020). Arsitektur Jawa Pada Wujud Bentuk Dan Ruang Masjid Agung Surakarta. Sinektika: Jurnal Arsitektur, 17(1). http://journals.ums.ac.id/index.php/sinektika.

Aizid, R. (2015). Sejarah Peradaban Islam Terlengkap: Periode Klasik, Pertengahn dan Modern. Diva Press.

Aizid, R. (2016). Sejarah Islam Nusantara: Dari Analisis Historis hingga Arkeologis tentang Penyebaran Islam di Indonesia. Diva Press.

Akbar, T. (2021). Arsitektur Masjid Jawa,. http://www.academia.edu.com/.

Fajri, Z., \& Aprilia Senja, R. (2005). Kamus Lengkap Bahasa Indonesia, Edisi Ketiga. Balai Pustaka.

Fanani, A. (2009). Arsitektur Masjid. Bentang Pustaka.

Fikriani, A. (2010). Arsitektur Islam: Seni Ruang dalam Peradaban Islam. El-Harakah: Jurnal Budaya Islam, 12(3). https://doi.org/DOI: https://doi.org/10.18860/el.v0i0.452

Gumilar, S. (2017). Historiografi Islam: Dari Masa Klasik Hingga Modern. CV Pustaka Setia.

Hakim, Moh. (2011). Makna Arsitektur Masjid Pakualaman Dalam Tinjauan Kosmologi Jawa. Analisa: Journal of Social Science and Religion, 18(2). https://doi.org/DOI: https://doi.org/10.18784/analisa.v18i2.134.

Handoko, W. (2013). Karakter Arsitektur Masjid Kuno dan Perkembangan Islam di Maluku. AMERTA: Jurnal Penelitian Dan Pengembangan Arkeologi, 31(1). https://doi.org/DOI: 10.24832/amt.v31i1.152 
Hikmah, N., Maulida, R., Nurlita, S., \& Fauzan Hidayatullah, A. (2020). Sinkretisme Arsitektur Islam Dan Nusantara Pada Bangunan Masjid Agung Jawa Tengah. Tazkiyya: Jurnal Keislaman, Kemasyarakatan Dan Kebudayaan, 21(1). http://jurnal.uinbanten.ac.id/index.php/tazkiya/article/view/2332.

Hitti, P. K. (2008). History of the Arabs. PT Serambi Ilmu.

Ismail, F. (2017). Sejarah dan Kebudayaan Islam; Periode Klasik (Abad 7-13 M). IRCiSoD.

Khoiriyah. (2014). Reorientasi Wawasan Sejarah Islam: Dari Arab sebelum Islam hingga Dinasti-dinasti Islam. Penerbit Teras.

Koentjaraningrat. (1990). Sejarah Teori Antropologi II. UI Press.

Koentjaraningrat. (2015). Pengantar Ilmu Antropologi. PT Rineka Cipta.

Kuntowijoyo. (2013). Pengantar Ilmu Sejarah. Tiara Wacana.

M. Asy'ari. (2007). Islam dan Seni. Hunafa: Jurnal Studia Islamika, 04(2). https://doi.org/DOI: https://doi.org/10.24239/jsi.v4i2.207.169-174

Ph. Subroto. (1982). Arkeologi: Humanisme dan Sains. JBA: Jurnal Berkala Arkeologi, 03(1). https://doi.org/DOI: 10.30883/jba.v3i1.294

Putra Mahardi, D. (2021). Adakah Pakem Arsitektur Masjid dalam Islam. https://alif.id/read/didin-putra-mahardi/adakah-pakem-arsitektur-masjid-dalam-islamb222547p/

Rachman, D., Ashadi, \& Hakim, L. (2018). Pencampuran Arsitektur Tradisiona dan Modern pada Perencanaan Taman Walisongo di Cirebon. PURWARUPA: Jurnal Arsitektur, 02(1). https://jurnal.umj.ac.id/index.php/purwarupa/article/view/2900.

Rizky Indriatuty, H., Rachman Efendi, A., \& Ibnu Saipudin, A. (2020). Bangunan Masjid Agung Banten sebagai Studi Sosial dan Budaya. Pattingalloang: Jurnal Pemikiran Pendidikan Dan Penelitian Kesejarahan, 07(2). https://doi.org/DOI: https://doi.org/10.26858/jp.v7i2.13517.

Rochym, A. (1983). Sejarah Arsitektur Islam: Sebuah Tinjauan. Angkasa.

Sativa. (2011). Islam atau Arsitektur Islami? NALARs: Jurnal Arsitektur, 10(1). https://doi.org/DOI: https://doi.org/10.24853/nalars.10.1.\%25p

Sunyoto, A. (2012). Atlas Walisongo: Buku Pertama yang Mengungkap Wali Songo Sebagai Fakta Sejarah. Penerbit IIMaN.

Sutiyono. (2010). Benturan Budaya Islam: Puritan \& Sinkretis. Kompas Media Nusantara.

Tjandrasasmita, U. (2009). Arkeologi Islam Nusantara. Kepustakaan Populer Gramedia.

Zaki, M. (2017). Kearifan Lokal Jawa Pada Wujud Bentuk Dan Ruang Arsitektur Masjid Tradisional Jawa (Studi Kasus Masjid Agung Demak) [Tesis]. Universitas Negeri Diponegoro. 